\title{
Inhibitory Effect of Maternal Alcohol Ingestion on Rat Pup Hepatic 25-Hydroxyvitamin D Production
}

\author{
M. MILNE AND D. T. BARAN \\ Departments of Orthopedics and Medicine, Univeristy of Massachusetts Medical Center, \\ Worcester, Massachusetts
}

\begin{abstract}
The mechanisms underlying the teratogenic effects of alcohol are unknown, and may reflect metabolic differences between adult and fetal tissues. The liver is the major site of alcohol metabolism and the sole site of 25 hydroxyvitamin D synthesis. We have compared 25-hydroxyvitamin D production in adult nonpregnant, maternal, and pup livers obtained from vitamin D-deficient animals and examined the effects of alcohol ingestion on hepatic vitamin D metabolism. 25 Hydroxyvitamin D production was comparable in adult nonpregnant and maternal livers, but was decreased in pup livers compared to their maternal controls $(1.4 \pm 0.2$ versus $0.6 \pm 0.1 \mathrm{pmol} / \mathrm{g}$ protein $/ \mathrm{h}, p<$ $0.001)$. Alcohol ingestion for 18 days had no effect on hepatic synthesis of 25 hydroxyvitamin $D$ in the adult livers, but inhibited production by the pup livers $(0.6 \pm 0.1$ versus $0.3 \pm 0.1 \mathrm{pmol} / \mathrm{g}$ protein $/ \mathrm{h}, p<0.02$ ). To assess the physiologic significance of these observations, the effect of alcohol on 25-hydroxyvitamin D levels in vitamin D-replete mothers and fetuses was determined. Alcohol had no effect on circulating 25 hydroxyvitamin $D$ levels in the mothers but lowered fetal 25 hydroxyvitamin $D$ content $(2.3 \pm 0.3$ versus $1.2 \pm 0.3 \mathrm{ng} / \mathrm{g}$ fetus, $p<0.02$ ) without altering fetal weight. The data indicate that differences exist in pup and adult hepatic metabolism of vitamin $D$ and that alcohol has inhibitory effects on pup liver function not expressed in adult tissues. (Pediatr Res 19: 102-104, 1985)
\end{abstract}

\section{Abbreviations}

25 hydroxyvitamin D, 25 OH D

1,25 dihydroxyvitamin $\mathrm{D}, 125(\mathrm{OH})_{2} \mathrm{D}$

The liver is the sole site of production of $25 \mathrm{OH} \mathrm{D} \mathrm{(1-3).}$ Although chronic alcohol ingestion in nonpregnant man has been shown to result in decreased $25 \mathrm{OH} \mathrm{D}$ blood levels $(4,5)$, hepatic vitamin D 25-hydroxylation appears to be normal in alcoholic liver disease $(5,6)$. This suggests that the decreased blood levels are due to poor dietary intake and lack of sunlight $(5,6)$. Also, alcohol ingestion in nonpregnant vitamin D-depleted rats does not inhibit the conversion of vitamin $\mathrm{D}$ to $25 \mathrm{OH} \mathrm{D}$ following a pharmacologic dose of vitamin D (7). However, no studies have examined the effect of alcohol on the production of $25 \mathrm{OH} \mathrm{D}$ by livers obtained from rats ingesting alcohol while pregnant, or exposed to alcohol in utero.

Received April 6, 1984; accepted August 16, 1984

Correspondence Dr. Daniel T. Baran, Department of Orthopedics, University of Massachusetts Medical Center, 55 Lake Avenue North, Worcester, MA 01605. Supported in part by a grant AM 27516 from the NIH.
Since alcohol ingestion during pregnancy has been reported to induce malformations specific to the fetus in man and rats (8), and since the liver is a major site of alcohol metabolism, we have compared the effects of ethanol on $25 \mathrm{OH} \mathrm{D}$ production by the livers of vitamin D-depleted adult nonpregnant, adult maternal rats and pups and on the $25 \mathrm{OH} \mathrm{D}$ content of alcohol-exposed vitamin D-replete fetuses. The data indicate that the ability of pup livers to produce $25 \mathrm{OH} \mathrm{D}$ is significantly diminished compared to their respective maternal livers, and that alcohol impairs $25 \mathrm{OH} D$ production by pup livers, but not by the livers of adult rats. This impairment results in decreased fetal $25 \mathrm{OH}$ D content.

\section{METHODS}

Three-week-old female weanling rats were fed a vitamin Ddeficient diet (Teklad, Madison, WI) containing $0.2 \%$ calcium and $0.4 \%$ phosphate for $8 \mathrm{wk}$. This results in vitamin D deficiency characterized by $25 \mathrm{OH} \mathrm{D}$ levels less than $1 \mathrm{ng} / \mathrm{ml}(9)$. The rachitic rats were mated with vitamin D-replete male rats in the absence of uv light. Five pregnant rats (day 6) were given $20 \%$ ethanol in their drinking water supplemented with maltose, $37 \mathrm{~g} / \mathrm{dl}$, to insure ingestion until 2 days after delivery and given the Teklad food ad libitum. Five control pregnant rats were pairfed with the Teklad food and maltose was isocalorically substituted for ethanol in the drinking water. Four nonpregnant female rats were administered alcohol and three control nonpregnant rats received maltose for the same 18 -day period as did the pregnant rats.

The adult rats were sacrificed under light ether anesthesia by exsanguination from the abdominal aorta, and the pups were sacrificed by decapitation. The livers were removed and the homogenate was prepared as we have previously described (10). The pup livers from an individual litter were pooled and two to three homogenate incubations performed on each of the five alcohol-treated and five control litters. Two pmoles of ${ }^{3} \mathrm{H}$-vitamin- $\mathrm{D}_{3}$ (Amersham Corp., Arlington Heights, IL) were added to each flask containing the liver homogenate in $25 \mu \mathrm{l}$ of $99 \%$ ethanol. Incubations were carried out for a maximum of $2 \mathrm{~h}$ at $37^{\circ} \mathrm{C}$ and 120 oscillations/min with continuous oxygenation at which time the reaction was terminated by addition of $25 \mathrm{ml}$ methanol plus $12.5 \mathrm{ml}$ chloroform. The resulting single phase was allowed to extract overnight at $4^{\circ} \mathrm{C}$. The extracts were filtered into separatory funnels to remove precipitated protein. Ten milliliters of water were added to each funnel to complete the separation of phases which occurred overnight at $4^{\circ} \mathrm{C} .{ }^{3} \mathrm{H}-25 \mathrm{OH}$ $\mathrm{D}$ production was determined by chromatography of the lipid fraction on Sephadex LH 20-100 columns as previously described (10) and identity confirmed by comigration with authentic cold $25 \mathrm{OH}$ D (courtesy Upjohn Co., Kalamazoo, MI).

The protein content of the liver homogenates was determined 
according to the procedure of Lowry et al. (11) with bovine serum albumin as standard. The amount of ${ }^{3} \mathrm{H}-25 \mathrm{OH}$ D produced was calculated from results obtained from chromatography and expressed in pmol/g liver protein/h.

The effect of ethanol exposure on $25 \mathrm{OH}$ D levels of vitamin D-replete animals was compared in adult pregnant rats and their fetuses. Ten 11-wk-old vitamin D-replete female rats were mated with vitamin D-replete male rats. Five pregnant rats (day 6) were given $20 \%$ ethanol in their drinking water and five pregnant control rats (day 6) were given the maltose solution. The two groups were pair-fed with Purina Rat Chow (St. Louis, MO). On day 22 of pregnancy, the rats were anesthetized with ether and the fetuses exposed by abdominal incision. Each fetus was removed, rinsed with $0.9 \%$ saline, and weighed. The mothers were exsanguinated and plasma $25 \mathrm{OH} \mathrm{D}$ levels were determined by the method of Haddad and Chyu (12). Twelve control and 12 alcohol-exposed fetuses were homogenized in $4 \mathrm{ml}$ of $0.9 \%$ saline. ${ }^{3} \mathrm{H}-25 \mathrm{OH} \mathrm{D}$ tracer $(300 \mathrm{cpm})$ was added to each homogenate and these were allowed to extract overnight in $12.5 \mathrm{ml} \mathrm{CHCl}_{3}$ and $25 \mathrm{ml} \mathrm{MeOH}$. The extracts were filtered into separatory funnels. Twevle and one-half milliliters $\mathrm{CHCl}_{3}$ and $10 \mathrm{ml} \mathrm{H}_{2} \mathrm{O}$ were added to complete the separation of phases overnight. The lipid phase was collected and dried. The residues were solubilized in $1 \mathrm{ml}$ of $33 \%$ ether in $n$-hexane $\left(\mathrm{V}^{-} / \mathrm{V}^{-}\right)$and applied to $4 \mathrm{~cm}$ Pasteur pipet columns of silicic acid. The total $25 \mathrm{OH} D$ level in the fetuses was then determined (12). All data are expressed as the mean $\pm S E M$, and the probability of difference determined by Student's $t$ test.

\section{RESULTS}

Alcohol constituted $52 \pm 3 \%$ of the total caloric intake of the pregnant rats and $58 \pm 3 \%$ of the total caloric intake of the nonpregnant rats. This level of alcohol consumption has previously been shown by us to result in blood levels of $98 \mathrm{mg} / \mathrm{dl}$ in pregnant rats (13) and $130 \mathrm{mg} / \mathrm{dl}$ in nonpregnant rats (14). Alcohol ingestion did not affect litter size. ${ }^{3} \mathrm{H}-25 \mathrm{OH} \mathrm{D}$ production was linear during the 2 -h incubation in all tissues. Although the pup rat liver was able to synthesize ${ }^{3} \mathrm{H}-25 \mathrm{OH} \mathrm{D}$, production by control pup liver homogenates was significantly less than maternal hepatic production $(1.4 \pm 0.2$ versus $0.6 \pm 0.1 \mathrm{pmol} / \mathrm{g}$ protein $/ \mathrm{h}, p<0.001$ ) (Table 1). Alcohol consumption had no effect on ${ }^{3} \mathrm{H}-25 \mathrm{OH} \mathrm{D}$ production by liver homogenates of nonpregnant rats $(1.3 \pm 0.3$ versus $1.0 \pm 0.1 \mathrm{pmol} / \mathrm{g}$ protein $/ \mathrm{h})$ or rats ingesting alcohol while pregnant $(1.4 \pm 0.2$ versus $1.2 \pm$ $0.1 \mathrm{pmol} / \mathrm{g}$ protein $/ \mathrm{h})$. However, maternal alcohol ingestion significantly inhibited pup hepatic ${ }^{3} \mathrm{H}-25 \mathrm{OH}$ D synthesis $(0.6 \pm$ 0.1 versus $0.3 \pm 0.1 \mathrm{pmol} / \mathrm{g}$ protein $/ \mathrm{h}, p<0.02$ ) (Table 1 ). Alcohol ingestion by vitamin D-replete rats did not affect maternal $25 \mathrm{OH} D$ blood levels $(12.3 \pm 1.2$ versus $11.6 \pm 0.5 \mathrm{ng} / \mathrm{ml})$ or fetal weight $(2.63 \pm 0.03$ versus $2.65 \pm 0.04 \mathrm{~g} / \mathrm{pup})$, but lowered fetal $25 \mathrm{OH} D$ content $(2.3 \pm 0.3$ versus $1.2 \pm 0.3 \mathrm{ng} / \mathrm{g}$ fetus, $p<0.02$ ) (Table 2).

Table 1. Effect of alcohol on $25 \mathrm{OH}$ D production by livers obtained from pregnant pup and nonpregnant vitamin Ddeficient rats*

\begin{tabular}{lccc}
\hline & $\begin{array}{c}\text { Pregnant } \\
\text { rats }\end{array}$ & Pups & $\begin{array}{c}\text { Nonpregnant } \\
\text { rats }\end{array}$ \\
\hline & \multicolumn{3}{c}{ (p mol/g protein/hr) } \\
\hline Control & $1.4 \pm 0.2$ & $0.6 \pm 0.1$ & $1.3 \pm 0.3$ \\
Alcohol & $1.2 \pm 0.1$ & $0.3 \pm 0.1$ & $1.0 \pm 0.1$ \\
Probability of difference & NS & $p<0.02$ & NS \\
\hline
\end{tabular}

* Hepatic $25 \mathrm{OH} \mathrm{D}$ production for each liver or litter was defined as the average of three homogenate incubations for the adult livers and two to three homogenate incubations on the pooled livers from each litter. Values represent the mean \pm SEM of five control and five alcoholexposed pregnant rat livers and the livers from each litter, and three control and four alcohol-exposed nonpregnant rat livers.
Table 2. Effect of alcohol on fetal wt and $25 \mathrm{OH} \mathrm{D}$ content of vitamin D-replete fetuses*

\begin{tabular}{lcc}
\hline & $\begin{array}{c}\text { Fetal wt } \\
(\mathrm{g})\end{array}$ & $\begin{array}{c}25 \mathrm{OH} \mathrm{D} \\
(\mathrm{ng} / \mathrm{g} \text { fetus })\end{array}$ \\
\hline Control & $2.63 \pm 0.03$ & $2.3 \pm 0.3$ \\
Alcohol & $2.65 \pm 0.04$ & $1.2 \pm 0.3$ \\
Probability of difference & NS & $p<0.02$ \\
\hline
\end{tabular}

* Values for fetal weight and fetal $25 \mathrm{OH} \mathrm{D}$ content represent the mean \pm SEM of 12 control and 12 alcohol-treated fetuses obtained from five control and five alcohol-exposed litters.

\section{DISCUSSION}

Previous studies in our laboratory have demonstrated that 25 $\mathrm{OH} \mathrm{D}$ and $1,25(\mathrm{OH})_{2} \mathrm{D}$ inhibit hepatic $25 \mathrm{OH} \mathrm{D}$ production in vitro (10). Recent observations in man indicate that treatment with $1,25(\mathrm{OH})_{2} \mathrm{D}$ impairs the conversion of administered vitamin D to $25 \mathrm{OH} \mathrm{D}(15)$ and lowers $25 \mathrm{OH} \mathrm{D}$ levels in postmenopausal women (16). Thus, it appears that the liver is capable of responding to increasing levels of $1,25(\mathrm{OH})_{2} \mathrm{D}$ by inhibiting production of the $25 \mathrm{OH} \mathrm{D}$ precursor and that mechanisms exist to regulate hepatic $25 \mathrm{OH} \mathrm{D}$ production.

Very little is known regarding the control of $25 \mathrm{OH} D$ synthesis, which occurs in the microsomes (17) and mitochondria (18) of the hepatocyte. The microsomal 25 -hydroxylation requires molecular oxygen and reduced pyridine nucleotide, appears to be stimulated by supernatnat protein, and behaves like a cytochrome P450-dependent monooxygenase (19). The mitochondrial 25-hydroxylase is catalyzed by a mixed function oxidase, depends on NADPH and ferrodoxin, and is inhibited by carbon monoxide, the latter suggesting that cytochrome $\mathrm{P} 450$ is involved (18). The hepatic microsomal 25-hydroxylation system is apparently regulated by the vitamin D status of the animal $(20,21)$ whereas the mitochondrial system does not appear to be affected by vitamin D status (18). Recent work has demonstrated that the reconstituted liver mitochondrial cytochrome $\mathrm{P} 450$ system active as a vitamin D 25-hydroxylase has characteristics different from the microsomal enzyme (22). This suggests that their control mechanisms might also differ.

The data in this report demonstrate that differences exist between the maternal and fetal hepatic metabolism of vitamin D. These differences may indicate either an alteration in the amount of mitochondrial or microsomal enzyme available, or a change in the affinity of enzyme for vitamin D. It is unlikely that these differences reflect varying levels of vitamin D metabolites in mothers and pups. $25 \mathrm{OH} \mathrm{D}$ levels in cord blood of vitamin D-replete rats correlate closely with maternal levels of $25 \mathrm{OH} \mathrm{D}(23)$. There is poor correlation between maternal and cord levels of $1,25(\mathrm{OH})_{2} \mathrm{D}$ in the vitamin D-replete rat (23), with cord levels being lower. However, since $1,25(\mathrm{OH})_{2} \mathrm{D}$ inhibits 25 $\mathrm{OH} D$ production in vitro (14) and in vivo $(15,16)$, lower pup levels of $1,25(\mathrm{OH})_{2} \mathrm{D}$ would not explain decreased pup hepatic synthesis of $25 \mathrm{OH} \mathrm{D}$ relative to maternal production. These differences between the ability of adult and pup hepatic tissues to metabolize vitamin D may underline the susceptibility of pup livers to alcohol-induced inhibition of $25 \mathrm{OH} \mathrm{D}$ synthesis. In preliminary studies we have demostrated that calcium inhibits synthesis of $25 \mathrm{OH} \mathrm{D}$ by liver homogenates in a dose-dependent fashion, with inhibition being demonstrated at a calcium concentration of $0.4 \mathrm{mM}(24)$. Coupled with the observation that chronic ethanol ingestion increases calcium uptake by liver microsomes (25), it is tempting to speculate that the effects of alcohol on pup hepatic $25 \mathrm{OH} \mathrm{D}$ production are mediated by enhanced susceptibility to alterations in calcium fluxes. Alternatively, ethanol rapidly crosses the placenta and it has been shown to retard growth and differentiation in cultured rat embryos during organogenesis (26), suggesting that the observed effects of alcohol may be the result of a direct toxic effect on the pup hepatic microsomes and/or mitochondria.

This study indicates that differences exist in the pup and adult 
hepatic 25-hydroxylation of vitamin D and that alcohol, while having no effect on $25 \mathrm{OH} \mathrm{D}$ production in adult livers, inhibits synthesis in pup livers. Alcohol-mediated decreases in pup hepatic $25 \mathrm{OH} \mathrm{D}$ production as well as decreases in $25 \mathrm{OH} \mathrm{D}$ transport from mother to fetus (13) may contribute to the diminished $25 \mathrm{OH} \mathrm{D}$ content of alcohol-exposed vitamin Dreplete pups.

\section{REFERENCES}

1. Ponchon G, Kennan AL, DeLuca HF 1969 Activation of vitamin D by the liver. J Clin Invest 48:2032

2. Olson EB Jr, Knutson JC, Bhattacharyya MH, DeLuca HF 1976 The effect of hepatectomy on the synthesis of 25 hydroxyvitamin $\mathrm{D}_{3}$. J Clin Invest 57:1213

3. Ponchon G, Deluca HF 1979 The role of the liver in the metabolism of vitamin D. J Clin Invest 48:1273

4. Lund B. Sorenson OH, Hilden M, Lund B 1977 The hepatic conversion of vitamin $D$ in alcoholics with varying degrees of liver affection. Acta Med Scand 202:221

5. Posner DB, Russell RM, Absood S, Connor TB, Davis C, Martin L, Williams JB, Norris AH, Merchant C 1978 Effective 25 -hydroxylation of vitamin $\mathrm{D}_{2}$ in alcoholic cirrhosis. Gastroenterology 74:866

6. Barragry JM, Long RG, France MW, Wills MR, Boucher BJ, Sherlock S 1979 Intestinal absorption of cholecalciferol in alcoholic liver disease and primary biliary cirrhosis. Gut 20:559

7. Gascon-Barre M 1982 Plasma $25 \mathrm{OH}$ D response to a pharmacological dose of vitamin $\mathrm{D}$ or $25 \mathrm{OH} \mathrm{D}$ during chronic ethanol administration in the rat. Horm Metabol Res 14:332

8. Streissguth AP, Lundesman-Dwyer S, Martin JC, Smith DW 1980 Teratogenic effects of alcohol in humans and laboratory animals. Science 209:353

9. Baran DT 1983 Effect of chronic (8 week) phenobarbital treatment on the metabolism of ${ }^{3} \mathrm{H}$-vitamin $\mathrm{D}$ by the perfused rachitic rat liver in vitro. Am J Physiol 245:E55

10. Baran DT, Milne M $19831,25(\mathrm{OH})_{2} \mathrm{D}$ induced inhibition of ${ }^{3} \mathrm{H}-25 \mathrm{OH}$ D production by the rachitic rat liver in vitro. Calcif Tissue Int 35:461

11. Lowry OH, Rosebrough NJ, Farr AL, Randall RJ 1951 Protein measurement with the folin-phenol reagent. I Biol Chem 193:265

12. Haddad JG, Chyu KJ 1971 Competitive protein binding assay for 25 hydroxycholecalciferol. J Clin Endocrinol Metab 33:992

13. Baran DT 1982 Alcohol-induced inhibition of fetal ${ }^{3} \mathrm{H}-25 \mathrm{OH} \mathrm{D}$ and ${ }^{14} \mathrm{C}-\alpha-$ aminoisobutyric acid accumulation in the pregnant rat. Endocrinology 111:1109

14. Baran DT, Bryant C, Robson D 1982 Alcohol induced alterations in calcium metabolism in the pregnant rat. Am J Clin Nutr $36: 41$

15. Bell NH, Shaw S, Turner RT 1984 Evidence that 1,25 dihydroxy-vitamin D inhibits the hepatic production of 25 hydroxyvitamin $D$ in man. $J$ Clin Invest 74:1540

16. Lore F, DiCairano G, Periti P, Caniggia A 1982 Effect of the administration of 1,25 dihydroxyvitamin $\mathrm{D}_{3}$ on serum levels of 25 hydroxyvitamin $\mathrm{D}$ in postmenopausal osteoporosis. Calcif Tissue Int 34:539

17. Bhattacharyya MH, DeLuca HF 1974 Subcellular location of rat liver calciferol25-hydroxylase. Arch Biochem Biophys 160:58

18. Bjorkhem I, Holmberg I 1978 Assay and properties of a mitochondrial 25 hydroxylase active on vitamin D. J Biol Chem 253:842

19. Madhok TC, DeLuca HF 1979 Characteristics of the rat liver microsomal enzyme system converting cholecalciferol into 25 hydroxycholecalciferol. Biochem J 184:491

20. Bhattacharyya MH, DeLuca HF 1973 The regulation of rat liver calciferol-25hydroxylase. J Biol Chem 248:2969

21. Delvin EE, Arabian A, Glorieux FH 1978 Kinetics of liver microsomal cholecalciferol-25-hydroxylase in vitamin $\mathrm{D}$ deplete and replete rats. Biochem J 172:417

22. Bjorkhem I, Holmberg I, Oftebro H, Pedersen JI 1980 Properties of a reconstituted vitamin D-25-hydroxylase from rat liver mitochondria. J Biol Chem 255:5244

23. Halloran BP, Barthell EN, DeLuca HF 1979 Vitamin D metabolism during pregnancy and lactation in the rat. Proc Nat Acad Sci 76:5549

24. Baran DT, Milne M 1983 Inhibitory effect of calcium on ${ }^{3} \mathrm{H}-25 \mathrm{OH} D$ production by the rachitic rat liver in vitro. Clin Res 31:693 (abstr)

25. Ponappa BC, Waring AJ, Hoek JB, Rottenberg H, Rubin E 1982 Chronic ethanol ingestion increases calcium uptake and resistance to molecular disordering by ethanol in liver microsomes. J Biol Chem 257:10141

26. Brown NA, Goulding EH, Fabri S 1979 Ethanol embryotoxocity: direct effects on mammalian embryos in vitro. Science 206:573

\title{
Fatty Acid Abnormalities in Cystic Fibrosis
}

\author{
PHILIP M. FARRELL, ELAINE H. MISCHLER, MICHAEL J. ENGLE, D. JEANNETTE BROWN, \\ AND SZE-MEI LAU
}

Departments of Pediatrics and Nutritional Sciences, University of Wisconsin-Madison, Madison, Wisconsin 53792

\begin{abstract}
Fatty acids were measured by gas chromatography in lipid extracts of plasma and tissues obtained from three categories of $\mathbf{4 6}$ patients with cystic fibrosis. Low levels of the major essential fatty acid linoleate were found in plasma total lipids of patients who had malabsorption but not in those without evidence of steatorrhea. Circulating arachidonic acid was only slightly decreased, and the unusual triene reflecting pathologically altered fatty acid metabolism (20:3 $\omega 9)$ was generally not detected, nor was the triene/tetraene ratio abnormal except for in
\end{abstract}

Received February 1, 1984; accepted August 24, 1984

Address for correspondence and reprint requests Philip M. Farrell, M.D., Ph.D. H4/428 Clinical Sciences Center, University of Wisconsin-Madison, 600 Highland Avenue, Madison, WI 53792

This study was made possible by a research grant and a CTR Center grant from the Cystic Fibrosis Foundation. P.M.F. was supported by a Pulmonary SCOR grant from National Institutes of Health (P50-HL-27358). M.J.E. is the recipient of Research Career Development Award KD4-HD-00350. two patients. There was no correlation between plasma linoleate and age, clinical severity score, or vitamin $E$ status. Decreased linoleate did correlate with two indices of malabsorption, namely plasma carotene $(r=0.64)$ and fecal fat excretion $(r=0.76)$. Our data therefore indicate that the abnormality in linoleate is associated with (secondary to) malabsorption of dietary fat despite pancreatic enzyme replacement therapy and consumption of a regular diet. The frequency of this alteration was determined to be quite high in 40 patients with steatorrhea, $85 \%$ of whom showed values below the lower limit of normal for plasma linoleate. It was of interest to find markedly decreased levels of linoleate in adipose tissue, cardiac muscle, and lung and lesser reductions in liver and psoas muscle taken at autopsies. Tissue arachidonic acid percentage was normal, however, and $20: 3 \omega 9$ was rarely present. Thus, the physiological significance of this common abnormality in 